\title{
MEMBANGUN DEFINISI GENETIS KUBUS MELALUI DISTORSI DAN MANIPULASI OBJEK SPASIAL
}

\author{
Feny Rita Fiantika ${ }^{1}$, I Ketut Budayasa ${ }^{2}$, Agung Lukito $^{3}$ \\ ${ }^{1}$ Universitas Nusantara PGRI Kediri \\ ${ }^{2,3}$ Pascasarjana Universitas Negeri Surabaya \\ fentfeny@gmail.com, fenyrita@unpkediri.ac.id
}

\begin{abstract}
Abstrak
Geometri merupakan salah satu materi yang sangat dekat dengan kehidupan kita. Terdapat berbagai bentuk geometri yang digunakan dalam design interior dan pola-pola dalam bangunan. Kedekatan konten geometri dalam kehidupan kita tersebut mendorong peneliti untuk menggali lebih dalam proses berpikir spasial siswa SD. Terdapat dua jenis representasi yaitu representasi internal dan representasi eksternal. Persepsi, abstraksi, distorsi dan hubungan antar objek merupakan elemen dari representasi internal, representasi eksternal mengungkapkan produk pemikiran tersebut dalam bentuk gambar, kata-kata (verbal), tabel, benda konkrit, atau simbol matematika yang digunakan untuk memahamkan diri sendiri dan orang lain.

Transformasi merupakan bagian dari representasi. Transformasi membutuhkan objek untuk dioperasikan dan representasi membutuhkan transformasi untuk menciptakan representasi. Kita membutuhkan representasi untuk mengomunikaskan ide-ide kita kepada orang lain dan transformasi sangat penting untuk membantu mengungkapkan representasi. Transformasi merupakan alat untuk mendeskripsikan representasi.

Subjek penelitian ini adalah siswa SD kelas V yang diberi sebuah masalah geometri dari objek 2 dimensi ke 3 dimensi. Hasil temuan penelitian adalah subjek mampu membangun sebuah definisi genetis kubus, dengan menggunakan berpikir analogis dalam penyusunan definisi tersebut. Subjek menggunakan karateristik yang sama yang terdapat pada jarring-jariing kubus dan kubus kubus untuk membangun definisi genetis kubus dan meyisihkan karakteristik yang tidak relevam pada kedua objek tersebut.
\end{abstract}

Kata kunci: Definisi Genetis, manipulasi, representasi internal, representasi eksternal, Persepsi, Distorsi, spasial

\begin{abstract}
Geometry is one of school material subject which close with our daily activities. They used geometry form concept to interior and exterior design. The closeness between geometry content and daily activities encourage author to explore how is spatial thinking elementary student. Two kinds of representations are internal representation and external representation. Representation internal include perception, distortion or abstraction and relationships between objects, external representation reveal the product of thought to image, words, table, concrete object, or mathematic symbols used to understand yourself and others.

Transformation is representation component. Transformation needs object to operate it, and representation needs transformation to create representation. Transformation is tool to descript representations.

Subject of the research is elementary school students grade $5^{\text {th }}$, the researcher gives them a problem of geometry object 2 dimensions to 3 dimensions The research findings are the subject be able to construct a genetic definition of the cube by using analogical thinking in the preparation of the definition.
\end{abstract}

Keywords: Genetis term, manipulation, internal representation, eksternal representation, peseption, distortion, spatial 


\section{PENDAHULUAN}

Geometri adalah salah satu objek kajian matematika yang penerapannya banyak dijumpai dalam kehidupan sehari-hari. Sesuai dengan pendapat Ontario, Federation Teacher (2008) yaitu:"Geometry is an important area of mathematics because it provides students with a for the world that surrounds them. Geometric forms can be found in the natural world as deeper appreciation well as in virtually all areas of human creativity and ingenuity". Artinya, geometri merupakan bagian penting dari matematika karena memberi siswa apresiasi mendalam untuk dunia di sekelilingnya.

Bentuk-bentuk geometris dapat ditemukan di alam maupun di hampir semua bidang kreativitas dan akal budi manusia. Meskipun objek-objek 3 dimensi sangat dekat dengan kehidupan kita mulai dari balita, namun beberapa penelitian mengemukakan bahwa masih banyak siswa yang mengalami kesulitan berkaitan dengan materi 3 dimensi. Hal ini sependapat dengan Ryu et all (2007), ...it was found that some students had difficulty in imagining a 3-dimensional object in space from its 2-dimensional representation in plane" Artinya telah ditemukan banyak siswa yang mengalami kesulitan mengimajinasikan objek ruang 3 dimensi dari representasi bangun datar 2 dimensi. Peneliti megembangkan sebuah masalah geometri yang ditujukan untuk menggali proses representasi dan transformasi representasi objek siswa kelas 5 sekolah dasar.

Terdapat dua jenis representasi yaitu representasi internal dan representasi eksternal. Representasi internal dari seseorang sulit untuk diamati secara langsung karena aktivitas merupakan aktivitas mental seseorang, aktivitas metal tersebut terdapat dalam pikiran seseorang. Aktivitas mental tersebut dapat disimpulkan atau diduga dengan melalui gambar, ungkapan verbal seseorang atau aktivitas lain yang dilakukan seseorang dan menggambarkan yang aktivitas mentalnya. Representasi terdiri dari unsur-unsur dan hubungan spasial maupun konseptual antara elemen-elemen dalam suatu kerangka acuan tertentu.

Proses representasi diawali dari pengkodean unsur-unsur atau elemen-elemen dan hubungan-hubungan yang mungkin terdapat di dalam unsur atau elemen tersebut. Pada proses pengkodean unsur-unsur tersebut tidak terjadi secara otomatis, namun dikaitkan dengan pengolahan informasi yang dimiliki sebelumnya dan saat ini sehingga diperoleh simpulan yang kompleks. Pengkodean elemen-elemen atau unsur-unsur suatu objek maupun hubunganhubungannya dilakukan dengan cara membedakan gambar atau objek yang akan dikodekan selanjutnya sifat-sifat unsur dan hubungan-hubungan yang ada diselaraskan dalam konteks tertentu hingga diperoleh kode. Pada proses pengkodean terjadi distorsi dan manipulasi kognitif. Proses distosi terjadi secara sistematis dalam mengangkat sifat-sifat atau ciri-ciri 
suatu objek dan menggugurkan sifat-sifat atau ciri-ciri objek yang tidak sesuai dengan kerangka acuannya.Istilah ini kita kenal dengan abstraksi.

Menurut Lutz (2009), terdapat dua jenis abstraksi yaitu abstraksi dipandang sebagai proses dan abstraksi dipandang sebagai produk. Abstraksi sebagai proses yaitu mengangkat sifat-sifat atau karaktersitik objek spasial dan menyisihkan sifat-sifat atau karakteristik yang tidak relevan. Proses ini mengandung distorsi karena terjadi penghapusan realita, hanya unsur atau karakteristik yang relevan saja yang digunakan. Abstraksi dipandang sebagai produk jika dari suatu abstraksi menghasilkan objek abstrak. Manipulasi kognitif dalam proses ini, memuat cara atau taktik yang terkait dengan intuisi hingga pengalaman yang dimilikinya yang digunakan untuk mengidentifikasi suatu objek, membandingkan hingga diperoleh nama atau label yang sesuai dengan kerangka acuannya.

Manipulasi menurut Buss (1992), Manipulation, the third proposed class of mechanisms, is defined as the means by which individuals intentionally (although not necessarily consciously) influence, alter, or shape those selected environments. Artinya manipulasi adalah sarana dimana individu dengan sengaja (walaupun tidak harus sadar) mempengaruhi, mengubah, atau bentuk yang dipilih Lingkungan. Pendapat ini mengisyaratkan terdapat suatu cara atau teknik yang sengaja digunakan oleh seseorang untuk mempengaruhi, mengubah objek untuk tujuan tertentu. Untuk mengomunikasikan produk pemikiran dari representasi internal diperlukan ungkapan yang berupa kata-kata verbal, simbol, maupun gambar visual yang merupakan wujud representasi eksternal yang dilakukan oleh seseorang. Dengan demikian representasi eksternal dikatakan dapat memfasilitasi memori jangka panjang dari konsep yang akan disampaikan, hal ini karena representasi eksternal menggunakan ungkapan berupa ungkapan berupa kata-kata verbal, simbol maupun gambar yang dapat memperpanjang ingatan seseorang dalam memahami suatu konsep.

Menurut NRC (2010), proses pengkodean meliputi: membedakan bangun datar, mengenali bentuk baik bentuk garis maupun susunan internal, mengevaluasi ukuran, membedakan tekstur, mengenali warna dan menentukan atribut lainnya. Jadi representasi internal adalah suatu proses internal yang melibatkan pengkodean, abstraksi, distorsi untuk membentuk suatu produk pemikiran yang berupa ungkapan dari ide-ide matematik yang merupakan bentuk pengganti dari suatu situasi masalah yang digunakan untuk menemukan solusi dari masalah yang sedang dihadapinya. Sedangkan Representasi eksternal adalah ungkapan-ungkapan dari ide matematika yang ditampilkan seseorang sebagai model atau bentuk pengganti dari suatu situasi masalah yang digunakan untuk menemukan solusi dari masalah yang sedang dihadapinya sebagai hasil dari interpretasi pikirannya. Suatu masalah 
dapat direpresentasikan melalui gambar, kata-kata (verbal), tabel, benda konkrit, atau simbol matematika. Baik pada representasi internal maupun eksternal terdapat manipulasi.

Perbedaan dari kedua representasi ini adalah representasi internal berupa produk pemikiran yang masih berada pada pikiran seseorang yang digunakan untuk memahamkan diri sendiri sedangkan representasi eksternal mengungkapkan produk pemikiran tersebut dalam bentuk gambar, kata-kata (verbal), tabel, benda konkrit, atau simbol matematika yang digunakan untuk memahamkan diri sendiri dan orang lain. Fiantika (2017), The preliminary studies have shown that every student has different kinds of style to construct it and the representation of their understanding. It depends on their habits and experiences. Artinya, pada studi pendahuluan menunjukkan bahwa setiap siswa mempunyai style yang berbeda dalam mengonstruksinya dan representasi dari pemahamannya. Hal ini tergantung pada kebiasaan dan pengalamannya.

Jadi, setiap orang mempunyai cara yang berbeda untuk merepresentasikan suatu objek, representasi yang diungkapkan seseorang terhadap suatu objek tersebut tergantung pada kebiasaan dan pengalaman yang dimiliki oleh seseorang tersebut. Melalui indiaktor yang disusun untuk mengetahui representasi internal yang memuat persepsi, distorsi, hubungan antar objek dan representasi eksternal yang memuat visual, verbal dan kinestetik ditemukan proses mengonstruksi definisi genetik kubus melalui analogi yang akan dibahas pada poin selanjutnya.

\section{METODE}

Penelitian ini merupakan penelitian kualitatif. Subjek penelitian adalah seorang siswa kelas 5 sekolah dasar bergaya belajar visual, berkemampuan sedang dengan kemampuan komunikasi baik. Siswa kelas 5 SD diberi tes gaya belajar untuk mengelompokkan siswa bergaya belajar visual, auditori dan kinestetik. Siswa bergaya belajar visual diberi tes masalah matematika untuk mengelompokkan dalam siswa berkemampuan tinggi, sedang dan kurang. Diplih siswa beremampuan sedang yang komunikatif. Subjek terpilih diberi masalah geometri yang mentransformasi objek 3 dimensi ke gambar objek 2 dimensi.

\section{Instrumen Penelitian}

Peneliti adalah instrumen utama dalam penelitian ini dan data digali dengan menggunakan instrumen tugas masalah geometri yang mentransformasi objek 3 dimensi ke gambar objek 2 dimensi, wawancara, catatan lapangan dan video recorder. 


\section{Uji Keabsahan Data}

Uji keabsahan data yang dilakukan adalah uji kredibilitas. Uji kredibilitas disebut juga validitas internal digunakan untuk mengetahui apakah data yang disajikan dapat mengukur apa yang hendak diukur, yaitu untuk mengecek apakah data yang telah diperoleh merupakan informasi yang valid dan telah menggambarkan keadaan subjek dalam menyelesaikan masalah geometri yang mentransformasi objek 3 dimensi ke gambar objek 2 dimensi. Untuk mengetahui data yang diperoleh kredibel atau valid secara internal, peneliti melakukan triangulasi waktu, tiangulasi teknik, member check, menambah ketekunan dalam membaca terkait dengan sumber informasi yang relevan dengan tulisan ini, memperpanjang pengamatan, diskusi dengan teman sejawat.

\section{HASIL DAN PEMBAHASAN}

\section{Hasil Penelitian}

Hasil penelitian menunjukkan pada representasi internal, subjek mendeskripsikan kubus sebagai bangun yang dibentuk oleh enam buah persegi bernoktah yang berukuran sama. Definisi yang disebutkan oleh subjek merupakan definisi genetik, karena subjek merepresentasikan terbentuknya sebuah kubus. Terdapat proses pengkodean yang melibatkan kubus dan jaring-jaring kubus yaitu subjek mengenali bentuk kubus dan jaring-jaring kubus.

Proses distorsi terdapat pada saat subjek membandingkan karakteristik kubus dan karakteristik jaring-jaring kubus, subjek hanya mengangkat sifat-sifat atau ciri-ciri yang sama yaitu keduanya mempunyai unsur pembangun yaitu enam buah persegi yang kongruen dan menggugurkan sifat-sifat atau ciri-ciri atau karakteristik yang berbeda dari keduanya yaitu keduanya memiliki bentuk fisik yang berbeda. Subjek mengkaitkan informasi tersebut dengan informasi yang dimiliki sebelumnya. Subjek membayangkan jaring-jaring kubus seperti robot transformer dan kubus seperti mobil-mobilan.

Dari peristiwa ini juga terdapat abstraksi yang menghasilkan distorsi yaitu subjek mengangkat sifat-sifat atau ciri-ciri atau karakteristik yang terdapat pada jaring-jaring kubus dan robot transformer, kubus dan mobil mobilan dan mengabaikan karakteristik yang berbeda yang melekat pada kedua pasang objek tersebut. Subjek memanipulasi kedua pasang objek tersebut sedemikian hingga diperoleh simpulan bahwa jaring-jaring kubus dapat digunakan untuk membangun kubus.

Dengan menggunakan ciri-ciri khusus yang melekat pada jaring-jaring kubus, subjek membangun definisi kubus melalui ciri-ciri jaring-jaring kubus, Subjek mengkaitkan informasi yang dipunyainya sedemikian hingga definisi kubus dikonstruk dengan menggunakan karakteristik jaring-jaring kubus. Subjek mendefinisikan kubus dengan cara 
menyebutkan bagaimana terbentuknya suatu kubus yang disebut sebagai definisi genetik dari sebuah kubus. Subjek mengubah bentuk jaring-jaring kubus menjadi kubus bayangan, subjek mengubah bentuk jaring-jaring kubus menjadi kubus bayangan seperti robot transformer yang berubah jadi mobil-mobilan.

Proses mengubah bentuk jaring jaring kubus menjadi kubus bayangan dengan menganalogikan dengan robot transformer menunjukkan representasi internal yang melibatkan penalaran yang telah dilakukan oleh subjek.

Terdapat proses pengkodean yang melibatkan hubungan antar objek yaitu jaring-jaring kubus berubah menjadi model kubus dan robot transformer yang berubah menjadi mobilmobilan. Untuk menentukan hubungan tersebut melibatkan distorsi dan manipulasi yaitu mengangkat ciri-ciri atau sifat-sifat yang berhubungan dengan jaring-jaring kubus berubah menjadi model kubus dan robot transformer yang berubah menjadi mobil-mobilan yaitu keduanya sama-sama mempunyai karakteristik yang sama yaitu berubah menjadi bentuk baru dan menggugurkan sifat-sifat atau ciri-ciri dari keduanya yang berkaitan dengan bentuk fisik dan atribut lainnya yang sama sekali berbeda dari keduanya.

Subjek memanipulasi informasi yang dipunyai terkait dengan jaring-jaring kubus berubah menjadi kubus bayangan dan robot transformer, membandingkan proses perubahan dari keduanya, memanipulasi keduanya sedemikian hingga jaring-jaring kubus berubah menjadi kubus banyangan dan sedemikan hingga robot transformer berubah menjadi mobilmobilan hingga diperoleh satu simpulan yang merupakan hasil akhir dari proses abstraksi yaitu diperoleh satu kesamaan dari keduanya yaitu keduanya mengalami "transformasi bentuk". Distorsi yang terjadi pada aktivitas ini adalah saat penghapusan karakteristk dari jaring-jaring kubus yang berubah menjadi kubus bayangan dan robot transformer yang berubah menjadi mobil-mobilan. Subjek memanipulasi jaring-jaring kubus dengan menganalogikan dengan robot transformer yang berubah menjadi mobil-mobilan. Pada kegiatan ini subjek menggunakan imajinasi transformasi dimensi yaitu membayangkan perubahan dari objek 2 Dimensi ke objek 3 Dimensi. 


\section{Pembahasan}

Berikut adalah gambar alur terbentuknya definisi genetis kubus dan transformasi bentuk dari jaring-jaring kubus menjadi kubus.

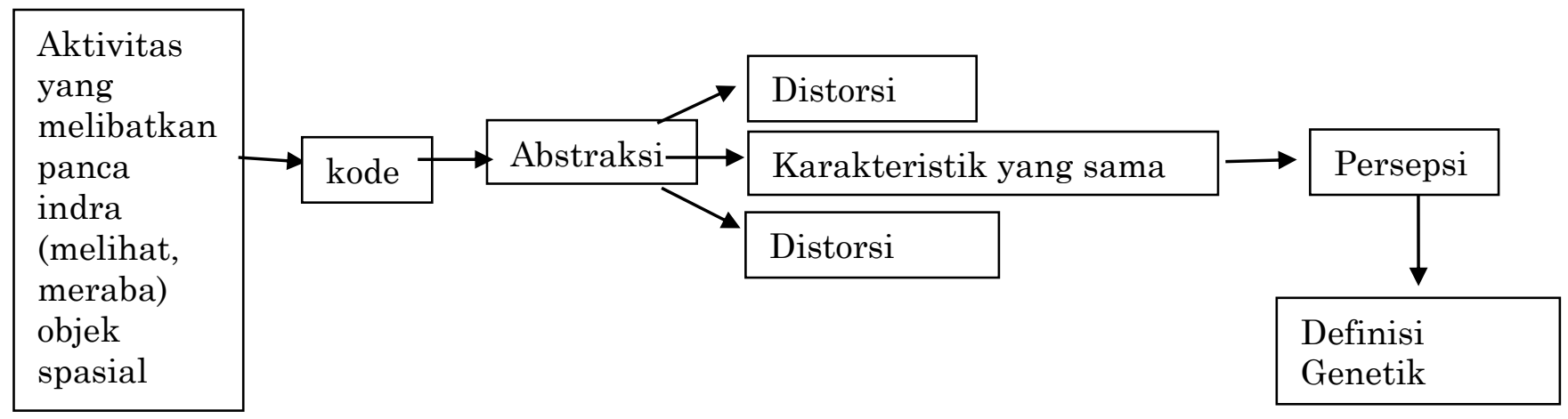

Gambar 1. Alur bepikir untuk membangun definisi genetis

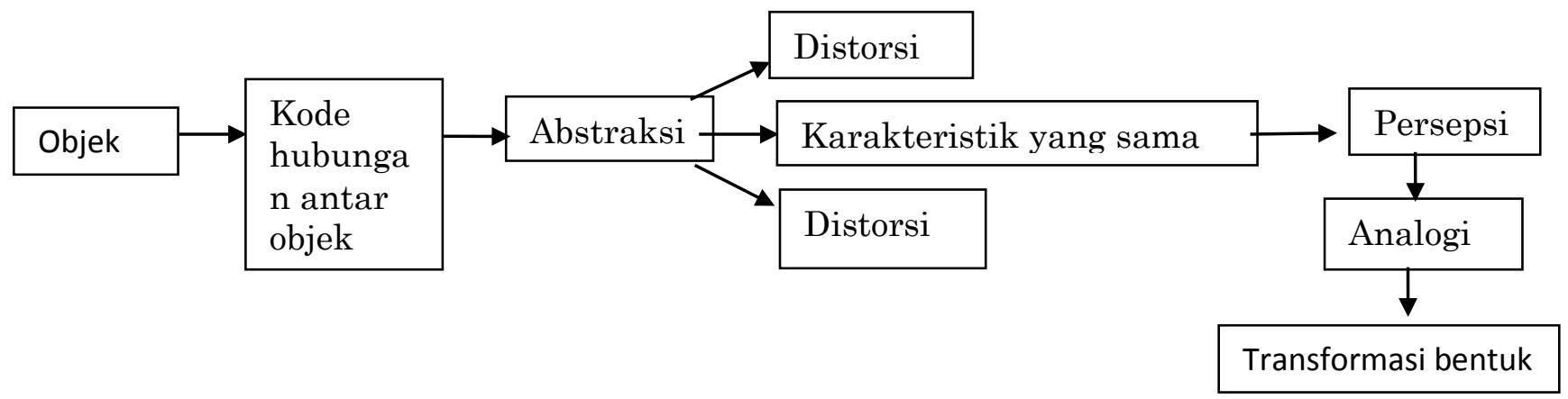

Keterangan gambar:

Gambar 2. Alur berpikir untuk membangun transformasi bentuk

$\square=$ Kegiatan $\quad \longrightarrow$ Alur yang melibatkan manipulasi

Manipulasi terjadi pada setiap alur pada proses pengkodean, abstraksi, distorsi dan penyimpulan. Distorsi merupakan hasil dari proses membandingkan pada proses abstraksi. Pada proses abstraksi mengangkat sifat-sifat/ cirri-ciri/ karaktersitik yang sama dan sebagai akibatnya terdapat distorsi yaitu menghapusan sifat-sifat/ ciri-ciri/ karaktersitik yang terdapat pada kedua objek tersebut. Hasil abstraksi merupakan persepsi yang disebut sebagai produk dari representasi internal. Produk pemikiran dari representasi internal perlu dikomunikasikan berupa visual, verbal maupun kinestetik yang disebut sebagai representasi eksternal. Representasi eksternal diperlukan agar representasi internal seseorang dapat dipahami oleh orang lain. Terdapat kesesuaian antara teori yang dikemukakan oleh Lutz (2009) yaitu distorsi merupakan hasil dari abstraksi. Temuan 
penelitian ini adalah terdapat manipulasi dalam setiap proses internal maupun eksternal, dan berpikir analogi digunakan untuk mengonstruk pengetahuan.

\section{SIMPULAN}

Manipulasi terjadi pada setiap alur yaitu pada proses pengkodean, distorsi, abstraksi dan bahkan kadang dalam penyimpulan. Distorsi merupakan hasil dari proses membandingkan pada proses abstraksi. Pada proses abstraksi mengangkat sifat-sifat/ ciri-ciri/ karaktersitik yang sama dan sebagai akibatnya terdapat distorsi yaitu menghapusan sifat-sifat/ ciri-ciri/ karaktersitik yang terdapat pada kedua objek tersebut. Persepsi merupakan hasil akhir dari representasi internal.. Representasi eksternal diperlukan untuk mengomunikasikan hasil dari sebuah representasi internal. Representasi eksternal dapat berupa informasi visual, verbal maupun kinestetik. Teknik analogi dapat digunakan membantu proses abstraksi. Pengalaman merupakan faktor pendukung dalam menyelesaikan pemecahan masalah.

\section{DAFTAR PUSTAKA}

Buss, David,M. (1992). Manipulation in Close Relationships: Five Personality Factors in Interactional Contex, Journal of Personality Duke University Press 60:2,.

Fiantika, FR. (2017). Elements Representation of Spatial Thinking, The 3rd International Conference on Mathematics, Science and Education 2016 Volume 824.

Lutz, Bastian (2009). Justifying Idealisation by Abstraction, Utrecth: Theorical philosophy Unit, Utrecth University.

Ryu, HyunAh, Chong, YeongOk, \& Song, SangHun. (2007). Mathematic Gifted Students Spatial Visualization Ability Of Solid Figures, Proceeding of the $31^{\text {st }}$ Conference of the International Group for the Psychology of Mathematics Education, Seoul: PME. Vol.4, pp.137-14.

NRC. (2006). Learning to Think Spatially, Washington, D.C: The National Academic Press.

Ontario, Federation Teacher. (2008). Geometry and Spatial Sense Grade 4 to 6, Canada: Portage and Main Press. 